\title{
Relation between Mir-196a2 and Mir-146a Polymorphisms and Susceptibility to DM1 in Egyptian Children
}

\author{
Hanaa Abdulfatah Mostafa ${ }^{1}$, Ashgan Abdalla Alghobashy ${ }^{1}$, Heba Fouad Pasha ${ }^{2}$, Yaser Mukhtar Alati ${ }^{* 1}$
}

Departments of ${ }^{1}$ Pediatrics and ${ }^{2}$ Medical Biochemistry, Faculty of Medicine, Zagazig University, Egypt.

*Corresponding author: Yaser Mukhtar Alati, Mobile: (+20)01018454325, E- mail: yaseralati01018@ gmail.com

\begin{abstract}
Background: MicroRNAs (miRNAs) are small non-coding RNA molecules that control the post-transcriptional gene expression. They play a pivotal role in the regulation of important physiological processes. Variations in miRNA genes coding for mature miRNA sequences have been implicated in several diseases, however, its role in type 1 diabetes mellitus (T1DM) is still underestimated. Objective: To investigate the association of miR-196a2 (rs11614913) and miR-146a (rs2910164) polymorphisms with T1DM in Egyptian children and adolescents.

Patients and Methods: A case-control study was done on 100 Egyptian children diagnosed with T1DM and additionally, 100 healthy age- and sex-matched subjects non-diabetic (control group) in the Department of Pediatrics and Endocrine and Metabolism Unit, Zagazig University Children Hospital from March 2021 to August 2021. Random blood sugar (RBS), glycosylated hemoglobin (HbA1c) and laboratory assessment for lipid profile were done for all patients.

Results: There was no significant difference between CC, CT and TT genotype in age, BMI, sex, onset, and disease duration, HbA1c, TC, LDL or HDL. There was a significant increasing in TG level in TT genotype compared to other genotypes. There was no significant differences between different genotypes in any of the studied parameters. Conclusion: The present study demonstrated that variants rs11614913 T/C and rs2910164 G/C were linked with the risk of T1DM. The data suggested that rs11614913 T/C and rs2910164 G/C could be considered as novel risk factors in the pathogenesis of T1DM in the Egyptian population.
\end{abstract}

Keywords: MIR146A, MIR196A2, miRNAs, T1DM.

\section{INTRODUCTION}

Type 1 diabetes mellitus (T1DM) results from a cellular mediated autoimmune destruction of pancreatic $\beta$-cells, leaving patients insulin-dependent for life. The triggering of autoimmunity against $\beta$-cells arises from a multifaceted interaction between multiple genetic and environmental risk factors ${ }^{(\mathbf{1})}$.

miRNAs are key regulators of gene expression and, like other genes, their coding sequences are subject to genetic variation. Polymorphisms in miRNA genes can have marked effects on miRNA functionality at all levels, including miRNA transcription, maturation and target specificity and, consequently, they may contribute to T1DM pathogenesis ${ }^{(2)}$. Recent studies have reported that miRNAs are critical posttranscriptional regulators of $30-50 \%$ of human gene expression and thus they may contribute in different pathological conditions. The SNPs in the sequences of miRNAs genes are relatively rare and highly conserved, which indicates the functional importance of these SNPs. The miR-196a2 rs11614913 $\mathrm{C}>\mathrm{T}$ polymorphism is located on chromosome 12 (12q13.13) ${ }^{(3)}$.

To date, miR-196a gene polymorphism of rs11614913 is one of the most investigated SNPs in case control studies concerning cancer and cardiac diseases but no previous study has reported its association with T1DM ${ }^{(4)}$. The association of miR196a rs11614913 with the previous diseases could be explained by findings reported by Hoffman and his colleagues (5) that miR-196a 2 expression was upregulated 9-fold in cells transfected with miR196a2-C allele but increased only by 4.5 -fold with miR-196a2-T allele. Other reporter demonstrated that increased expression of miR-196a2 was associated with the $\mathrm{C}$ allele ${ }^{(6)}$.

Currently, different case control studies have put the spotlight on miR-196a2 also in various human diseases regarding its role in developmental control, regulation of immune response and regulation of cell differentiation and migration. Jameel $\boldsymbol{e t}$ al. ${ }^{(3)}$ study found that miR-196a2 polymorphism was associated with diabetes disease. The study of Assmann et al. (7) indicates that miR-146a rs2910164 polymorphisms are associated with protection for T1DM in Brazilian populations. These associations are biological plausible considering the involvement of miR-146a in immunity and inflammation, which are key players in T1DM pathogenesis.

The aim of this study was to investigate the association of miR-196a2 (rs11614913) and miR-146a (rs2910164) polymorphisms with T1DM in Egyptian children and adolescents.

\section{PATIENTS AND METHODS}

A case-control study design was conducted on 100 Egyptian children diagnosed with T1DM aged from 3 to 18 years and 100 healthy age- and sexmatched subjects were selected as non-diabetic group (controls) recruited from the Department of Pediatrics and Endocrine and Metabolism Unit, Zagazig 
University Children Hospital from March 2021 to Aug 2021.

\section{Ethical considerations:}

Written informed consent was obtained from all children's' parents or their relatives and the study was approved by the Research Ethical Committee of Faculty of Medicine, Zagazig University (International review board IRB\#:66323-1-2021). The study was done according to The Code of Ethics of the World Medical Association (Declaration of Helsinki) for studies involving humans.

Inclusion criteria: Patients diagnosed with T1DM according to the criteria of American Diabetes Association guideline, and all included cases were diagnosed as TIDM using $\mathrm{C}$ peptide protein test and were under regular treatment with human insulin therapy.

Exclusion criteria: T2DM or specific diabetes.

Detailed history was taken from included patients including the following:

Full history taking included: Age and sex, detailed medical history including; chronological age, duration and age at onset of diabetes, type and dose of insulin, compliance to diet and insulin therapy, detailed dietetic history in addition to family history of diabetes, hypertension, coronary heart disease and stroke, and history suggestive of diabetic microvascular and macrovascular complications.

Thorough clinical examination including height, weight, waist circumference (WC), body mass index (BMI=weight in $\mathrm{kg} /$ height $^{2}$ in meters).

Biochemical assessment: Random blood sugar (RBS), glycosylated hemoglobin (HbA1c), Laboratory assessment for lipid profile including: serum total cholesterol (TC), serum triglycerides (TG), high density lipoprotein-cholesterol (HDL-C) and low density lipoprotein-cholesterol $($ LDL-C) $=$ TC-(HDLC)-(TG/5).

\section{Genotyping and analysis of polymorphisms: Expression of miR-146a:}

Plates were positioned in a real-time PCR thermal cycler (ViiA7 Real-Time PCR System; Thermo Fisher Scientific (USA) and heated for $10 \mathrm{~min}$ at $95^{\circ} \mathrm{C}$, followed by 50 cycles of $95^{\circ} \mathrm{C}$ for $15 \mathrm{~s}$ and $62^{\circ} \mathrm{C}$ for $1 \mathrm{~min}$. Only polymorphisms that have minor allele frequencies higher than $1 \%$ was considered.

\section{Expression of miR-196a2:}

RNA is isolated using RNeasy Mini Kit (Qiagen, Hilden, Germany) according to the manufacturer's instructions, then the extracted miRNA was reverse transcribed using a miScript reverse transcription (RT) kit (Qiagen, Hilden, Germany). Storage of cDNA specimens was done at $-80{ }^{\circ} \mathrm{C}$. Further qRT-PCR analysis was performed using miScript SYBR green PCR kit (Qiagen, Hilden, Germany). For the quantification of miR-196a2, we used Hs_miR-196a*_1 miScript Primer Assay (Assay ID MS00008960, Qiagen, Germany). QPCR was run on Applied Technologies' Stratagene Mx3000P (USA), according to the manufacturer's recommendation.

\section{Statistical Analysis:}

The collected data were entered to and analyzed by computer using Statistical Package of the Social Sciences version 25 (SPSS). Results were presented by tables and graphs. Quantitative data were presented as mean and standard deviation and were compared by independent t-test or one way ANOVA test. Qualitative data were presented as frequencies and proportions. Pearson Chi square test $\left(\chi^{2}\right)$ or Fisher's exact were used to analyze qualitative independent data. $\mathrm{P}$ value of $\leq 0.05$ was taken as significant.

\section{RESULTS}

Table 1 shows that there was no statistical significance difference between the studied groups as regard age, BMI and sex distribution.

Table (1): Demographic data of the studied groups

\begin{tabular}{||c|c|c|c|c||}
\hline Variable & $\begin{array}{c}\text { Cases } \\
(\boldsymbol{n = 1 0 0})\end{array}$ & $\begin{array}{c}\text { Control } \\
(\mathbf{n = 1 0 0})\end{array}$ & Sig. test & P value \\
\hline \hline $\begin{array}{c}\text { Age (years) } \\
\text { Mean } \pm \text { SD } \\
\text { Range }\end{array}$ & $\begin{array}{c}12.55 \pm 3.56 \\
3-18\end{array}$ & $\begin{array}{c}13.19 \pm 2.77 \\
4-17\end{array}$ & $\boldsymbol{t}=1.42$ & 0.16 \\
\hline $\begin{array}{c}\text { BMI (Kg/m }) \\
\text { Mean } \pm \text { SD } \\
\text { Range }\end{array}$ & $\begin{array}{c}17.8 \pm 4.63 \\
12.7-25.2\end{array}$ & $\begin{array}{c}18.3 \pm 4.90 \\
10.9-25\end{array}$ & $\boldsymbol{t}=0.74$ & 0.46 \\
\hline $\begin{array}{c}\text { Sex (\%) } \\
\text { Male } \\
\text { Female }\end{array}$ & $\begin{array}{c}57(57.0 \%) \\
43(43.0 \%)\end{array}$ & $\begin{array}{c}48(48.0 \%) \\
52(52 \%)\end{array}$ & $\chi^{2}=1.62$ & 0.20 \\
\hline
\end{tabular}

SD: Standard deviation $\mathrm{t}$ : Independent $\mathrm{t}$ test $\chi^{2}$ : Chi square test

Table 2 shows that, the age of onset and duration of T1DM among cases group. 
Table (2): History of the cases group $(n=100)$

\begin{tabular}{|l|c|}
\hline \multicolumn{1}{|c|}{ Variable } & Cases $(\mathbf{n}=\mathbf{1 0 0})$ \\
\hline \hline $\begin{array}{l}\text { Age of onset (years): } \\
\text { Mean } \pm \text { SD } \\
\text { Range }\end{array}$ & $6.45 \pm 2.01$ \\
& $2.5-13$ \\
\hline $\begin{array}{l}\text { Disease Duration } \\
\text { (years): } \\
\text { Mean } \pm \text { SD } \\
\text { Range }\end{array}$ & $7.66 \pm 2.5$ \\
\hline
\end{tabular}

\section{SD: Standard deviation}

This table shows that, there was a statistical significant increasing in $\mathrm{HbA1c}$, cholesterol, TG and LDL among cases compared to control group. But there was no statistical significant difference between the studied groups in HDL level.

Table (3): Laboratory findings among the studied groups

\begin{tabular}{|c|c|c|c|c|}
\hline Variable & $\begin{array}{c}\text { Cases } \\
(n=100) \\
\end{array}$ & $\begin{array}{l}\text { Control } \\
(\mathrm{n}=100)\end{array}$ & $\begin{array}{c}t- \\
\text { test } \\
\end{array}$ & $P$ value \\
\hline $\begin{array}{l}\text { HbA1c } \\
(\%) \\
\text { Mean } \pm \text { SD }\end{array}$ & $\begin{array}{l}8.2 \pm \\
2.3\end{array}$ & $\begin{array}{l}5.1 \pm \\
0.61\end{array}$ & 13.03 & $<0.001 * *$ \\
\hline $\begin{array}{l}\text { Cl } \\
(\mathbf{m g} / \mathbf{d l}) \\
\text { Mean } \pm \text { SD }\end{array}$ & $\begin{array}{r}148.12 \\
\pm 35.67 \\
\end{array}$ & $\begin{array}{r}126.34 \\
\pm 28.94 \\
\end{array}$ & 4.74 & $<0.001 * *$ \\
\hline $\begin{array}{l}\text { TG } \\
\text { (mg/dl) } \\
\quad \text { Mean } \\
\pm \text { SD }\end{array}$ & $\begin{array}{c}90.31 \pm \\
9.85\end{array}$ & $\begin{array}{c}64.28 \pm \\
2.14\end{array}$ & 7.23 & $<0.001 * *$ \\
\hline $\begin{array}{l}\mathbf{L D L} \\
(\mathbf{m g} / \mathbf{d l}) \\
\text { Mean } \pm \text { SD }\end{array}$ & $\begin{array}{l}102.72 \\
\pm 3.23\end{array}$ & $\begin{array}{c}94.34 \pm \\
2.39\end{array}$ & 2.26 & $0.02 *$ \\
\hline $\begin{array}{l}\text { HDL } \\
(\mathbf{m g} / \mathbf{d l}) \\
\text { Mean } \pm \text { SD }\end{array}$ & $\begin{array}{c}50.21 \pm \\
8.5\end{array}$ & $\begin{array}{c}51.4 \pm \\
7.96\end{array}$ & 1.02 & 0.31 \\
\hline
\end{tabular}

Cl: Cholesterol, TG: Triglyceride, LDL: Low density lipoprotein, HDL: High density lipoprotein, SD: Standard deviation, *: Significant, **: Highly significant

Table 4 shows that there was a statistical significant increase in frequency of CC genotype of miR-146a among cases that had CC genotype in miR196a2. However, there was a statistical significant increasing in frequency of GG genotype of miR-146a among cases that had TT genotype in miR-196a2.
Table (4): Relation between miR-196a2 and miR-146a among cases group $(\mathrm{n}=100)$

\begin{tabular}{|c|c|c|c|c|c|}
\hline Variable & $\begin{array}{c}\mathrm{CC} \\
(\mathrm{n}=40) \\
\end{array}$ & $\begin{array}{c}\mathbf{C T} \\
(\mathbf{n}=\mathbf{3 6})\end{array}$ & $\begin{array}{c}\text { TT } \\
(n=24) \\
\end{array}$ & $\chi^{2}$ & $\begin{array}{c}\mathbf{P} \\
\text { value }\end{array}$ \\
\hline miR146a & & & & & \multirow{4}{*}{$\stackrel{<}{<.001^{* *}}$} \\
\hline $\begin{array}{l}\mathrm{GG} \\
(n=58)\end{array}$ & $\begin{array}{c}17 \\
(20)\end{array}$ & $\begin{array}{c}19 \\
(32.8 \%)\end{array}$ & 22 & \multirow{3}{*}{20.4} & \\
\hline $\begin{array}{l}\mathrm{GC} \\
(n=34)\end{array}$ & $\begin{array}{c}(29.3 \%) \\
16\end{array}$ & $\begin{array}{c}16 \\
(47.1 \%)\end{array}$ & $\begin{array}{l}(37.9 \%) \\
2(5.8 \%)\end{array}$ & & \\
\hline $\begin{array}{l}\mathrm{CC} \\
(n=8)\end{array}$ & $7(\mathbf{8 7 . 5})$ & $\begin{array}{c}1 \\
(12.5 \%)\end{array}$ & $0(0.0 \%)$ & & \\
\hline
\end{tabular}

$\chi^{2}$ :Chi square test $* *$ : Highly significant

Table 5 shows that there was no statistical significant difference between CC, CT and TT genotype in age, BMI, sex, onset, disease duration, HbA1c, TC, LDL or HDL; but there was a statistical significant increasing in TG level in TT genotype compared to other genotypes.

Table (5): Relation between miR-196a2 (rs11614913) polymorphism and different parameters among cases group

\begin{tabular}{|c|c|c|c|c|c|}
\hline Variable & $\begin{array}{c}C C \\
(n=40)\end{array}$ & $\begin{array}{c}\text { CT } \\
(n=36)\end{array}$ & $\begin{array}{c}\text { TT } \\
(n=24)\end{array}$ & $\begin{array}{l}\text { Sig. } \\
\text { test }\end{array}$ & $\begin{array}{c}P \\
\text { value }\end{array}$ \\
\hline $\begin{array}{l}\text { Age } \\
\text { (years) } \\
\text { Mean } \pm \text { SD }\end{array}$ & $\begin{array}{c}11.96 \pm \\
3.5\end{array}$ & $\begin{array}{c}12.4 \pm 3 . \\
18\end{array}$ & $\begin{array}{c}12.84 \pm \\
3.41\end{array}$ & 0.52 & 0.59 \\
\hline $\begin{array}{l}\text { BMI } \\
\left(\mathbf{K g} / \mathbf{m}^{2}\right) \\
\text { Mean } \pm \text { SD }\end{array}$ & $\begin{array}{c}18.05 \pm \\
5.23\end{array}$ & $\begin{array}{c}17.81 \pm \\
4.9\end{array}$ & $\begin{array}{c}18.3 \pm \\
5.5 \\
\end{array}$ & 0.07 & 0.94 \\
\hline $\begin{array}{l}\text { Sex } \\
(\mathbf{m g} / \mathbf{d l}) \\
\text { Male } \\
\text { Female }\end{array}$ & $\begin{array}{c}23 \\
(40.3 \%) \\
17 \\
(39.5 \%)\end{array}$ & $\begin{array}{c}19 \\
(33.3 \%) \\
17 \\
(39.5 \%)\end{array}$ & $\begin{array}{c}15 \\
(26.3 \%) \\
9 \\
(20.9 \%)\end{array}$ & 0.56 & 0.75 \\
\hline $\begin{array}{l}\begin{array}{l}\text { Age of } \\
\text { onset } \\
\text { (years) }\end{array} \\
\text { Mean } \pm \text { SD }\end{array}$ & $\begin{array}{c}5.23 \pm \\
1.67\end{array}$ & $\begin{array}{l}5.5 \pm \\
1.81\end{array}$ & $\begin{array}{c}6.14 \pm \\
2.02\end{array}$ & 1.92 & 0.15 \\
\hline $\begin{array}{l}\text { Duration } \\
\text { (years) } \\
\text { Mean } \pm S D\end{array}$ & $\begin{array}{c}6.95 \pm \\
2.37\end{array}$ & $\begin{array}{c}7.31 \pm \\
2.25\end{array}$ & $\begin{array}{c}7.84 \pm \\
2.56\end{array}$ & 1.06 & 0.35 \\
\hline $\begin{array}{l}\text { HbA1c } \\
(\%) \\
\text { Mean } \pm \text { SD }\end{array}$ & $\begin{array}{l}7.7 \pm \\
1.35\end{array}$ & $\begin{array}{l}7.9 \pm \\
1.46\end{array}$ & $\begin{array}{c}8.41 \pm \\
2.8\end{array}$ & 0.61 & 0.54 \\
\hline $\begin{array}{l}\text { Cl }(\mathbf{m g} / \mathbf{d l}) \\
\text { Mean } \pm S D\end{array}$ & $\begin{array}{c}151.23 \\
\pm 9.24\end{array}$ & $\begin{array}{c}147.23 \\
\pm 6.28\end{array}$ & $\begin{array}{c}150.24 \\
\pm 34.6 \\
\end{array}$ & 0.12 & 0.89 \\
\hline $\begin{array}{l}\text { TG }(\mathbf{m g} / \mathbf{d l}) \\
\text { Mean } \pm \text { SD }\end{array}$ & \begin{tabular}{|c|}
$82.33 \pm$ \\
6.97 \\
\end{tabular} & $\begin{array}{c}83.83 \pm \\
5.37 \\
\end{array}$ & $\begin{array}{c}98.16 \pm \\
30.01 \\
\end{array}$ & 3.51 & $0.03 *$ \\
\hline $\begin{array}{l}\text { LDL } \\
(\mathbf{m g} / \mathbf{d l}) \\
\text { Mean } \pm \text { SD }\end{array}$ & \begin{tabular}{|c|}
$100.3 \pm$ \\
3.45 \\
\end{tabular} & $\begin{array}{l}105 \pm \\
3.19 \\
\end{array}$ & $\begin{array}{c}103.44 \\
\pm 3.5 \\
\end{array}$ & 0.22 & 0.80 \\
\hline $\begin{array}{l}\text { HDL } \\
(\mathbf{m g} / \mathbf{d l}) \\
\text { Mean } \pm \text { SD }\end{array}$ & $\begin{array}{c}51.9 \pm \\
8.16 \\
\end{array}$ & $\begin{array}{r}49.14 \\
\pm 7.96 \\
\end{array}$ & $\begin{array}{l}50.01 \\
\pm 7.94 \\
\end{array}$ & 1.17 & 0.32 \\
\hline
\end{tabular}

Test: F ANOVA test and $\chi^{2}$ : Chi square test *: Significant. 


\section{DISCUSSION}

Growing evidence indicates that microRNAs (miRNAs) have a key role in processes involved in T1DM pathogenesis, including immune system functions and $\beta$-cell metabolism and death. Although dysregulated miRNA profiles have been identified in T1DM patients, results are inconclusive; with only few miRNAs being consistently dysregulated among studies ${ }^{(8)}$. The miR-146a rs2910164 polymorphisms were associated with protection for T1DM in Brazilian children. These associations are biological plausible considering the involvement of miR-146a in immunity and inflammation, which are key players in T1DM pathogenesis ${ }^{(7)}$.

To date, no study has evaluated the association between polymorphisms in miR-146a, and miR196a2 genes and T1DM development. So, the current study aimed to investigate the association of miR196a2 (rs11614913) and miR-146a (rs2910164) polymorphisms with the susceptibility of T1DM in Egyptian children and adolescents at Zagazig University Children Hospital. The study population consisted of 100 Egyptian children diagnosed with T1DM and 100 healthy age- and sex-matched subjects were selected as non-diabetic group (controls).

The current study revealed that, there were no statistical significant differences between the studied groups in age, BMI or sex distribution. Mean age and mean BMI were insignificantly higher in control subjects than in T1DM patients. These results were in accordance with the study of Assmann et al. ${ }^{(7)}$.

However, the age of onset of T1DM among cases group ranged from 2.5 to 13 years with mean 6.45 years while duration of diabetes ranged from 6 months to 14 years with mean 7.66 years. Similarly, Hassan et al. ${ }^{(9)}$ reported that the mean age at onset of diabetes in the studied group was 8.2 2.6 (range 2.5$14.5)$ years, and the mean duration of diabetes was 4.3 \pm 2.7 (range 1.0-12.0) years.

Regarding the laboratory findings among the studied groups, the current study revealed that, there was a statistical significance increase in $\mathrm{HbA1c}$, cholesterol, TG and LDL among cases with T1DM compared to control group; but there was no statistical significance difference in HDL levels between the studied groups. These findings were in agreement with Hassan et al. ${ }^{(9)}$ who reported that, dyslipidemia was found in a significantly higher percentage of children and adolescents with T1DM (65\%) compared to that of the non-diabetic control group (28.2\%).

Regarding the relation between miR-196a2 and miR146a genotype polymorphism, the current study revealed that, there was a statistical significant increase in frequency of CC genotype of miR-146a among cases that had CC genotype in miR-196a2. Also there was a statistical significand increase in frequency of GG genotype of miR-146a among cases that had TT genotype in miR-196a2. These findings were going with the study of Khan $\boldsymbol{e t}$ al. ${ }^{(10)}$.

A previous study has shown that miR-196a rs 11614913 T/C is linked with DM, Downregulation of its mature miRNA may play a pivotal role in T1DM. The study of Khan et al. ${ }^{(10)}$ found that the genotype TT $(\mathrm{n}=76 / 22.4 \%)$ of $\mathrm{rs} 11614913 \mathrm{~T} / \mathrm{C}$ was more frequent in cases as compared to controls $(\mathrm{n}=$ $33 / 13.98 \%)$. On the other hand, the genotype CC was more common in the control group $(\mathrm{n}=130 / 38.46 \%)$ than patients $(\mathrm{n}=84 / 35.59 \%)$. In patients, the heterozygote $\mathrm{CT}$ was more common $(\mathrm{n}=$ $178 / 52.66 \%)$ than the control group (73/21.59\%).

Comparison of alleles $\mathrm{C}$ and $\mathrm{T}$ showed a reduced risk for the $\mathrm{C}$ allele $(\mathrm{OR}=0.4377)$. Following the results of Ibrahim et al. ${ }^{(5)}$, in a study carried out in Cairo, Egypt showed that the frequency of TT genotype was more common in patients than the healthy individuals. In support of this study, this study also found a significantly higher frequency of the $\mathrm{T}$ allele in patients than in controls $(41.7 \%$ vs. $31.3 \%)$, while the $\mathrm{C}$ allele was more frequent in controls. The study stated that the association of the TT genotype with T1DM remained significant. The study also reported decreased relative expression of miR-196a 2 in patients compared to controls.

A previous study suggested that miR-146a plays a crucial role in the prognosis of DM by contributing to the metabolism, proliferation, and death of $\beta$-cell. It can be detected in serum, T cells, and $\alpha$ and $\beta$-cells of patients with DM, supposing that the miR-146a is a therapeutic target and potential biomarker (10). A previous study demonstrated that rs2910164 G/C leads to an unstable pre-miR-146a structure ${ }^{(3)}$. The study of Khan et al. ${ }^{(10)}$ was carried out in 94 patients and 69 healthy individuals. By applying a co-dominant statistical model GG vs GC vs $\mathrm{CC}$, a significant difference in genotype frequencies was observed $(p$-value $=0.0001)$. The genotype GG was more frequent in control group (62.3\%) as compared to diabetes patients $(13.8 \%)$, whereas the genotype $\mathrm{GC}$ was more common in patients $(52.1 \%)$ as compared to control $(23.1 \%)$. The homozygote CC was also more common in patients $(34.0 \%)$ than in control (14.5\%). The genotype GG reduced the risk of diabetes with an odds ratio of 0.2439 (CI $=0.1524$ 0.3902 ), whereas the recessive model showed an increased risk for the genotype $\mathrm{CC}$ OR $=2.123(\mathrm{CI}=$ 1.118-4.033).

Khan et al.'s (10) report regarding the comparison of the two alleles ( $\mathrm{G}$ and $\mathrm{C}$ ) showed a reduced risk for $\mathrm{G}$ allele $0.2439(\mathrm{CI}=0.1524-0.3902)$. Thus, it can be concluded that the $\mathrm{C}$ allele of rs2910164 G/C in miR-146a increases the risk of DM.

Regarding the relation between miR196a2 and miR146a genotypes and different parameters (demographic characteristic data and laboratory findings), the current study revealed that, there were no statistical significant differences between CC, CT and 
TT genotype in age, BMI, sex, onset, duration, HbAlc, TC, LDL or HDL but there was a statistical significant increase in TG level in TT genotype compare to other genotypes.

Age, gender, age at T1DM diagnosis, BMI, lipid profile, and $\mathrm{HbA} 1 \mathrm{c}$ were similar between subjects carrying the minor alleles of the miR146a rs2910164, and miR-196a2 rs11614913

polymorphisms, analyzed individually, and subjects carrying ancestral homozygous genotypes $(P>0.05)$. However, T1DM patients carrying the miR196 rs 11614913 C allele (dominant model) had lower fasting plasma glucose levels compared to patients with the G/G genotype (127.0 $\pm 65.4 \mathrm{vs}$ $180.4 \pm 107.6 ; \mathrm{P}=0.001)$. In non-diabetic subjects, age, gender, $\mathrm{HbA1c}$, and BMI, were similar between different genotypes of the analyzed polymorphisms (dominant model, all $\mathrm{P}>0.05)^{(7)}$.

\section{CONCLUSION}

The present study demonstrated that variants rs11614913 T/C and rs2910164 G/C were linked with the risk of T1DM. The data suggested that rs11614913 $\mathrm{T} / \mathrm{C}$ and $\mathrm{rs} 2910164 \mathrm{G} / \mathrm{C}$ could be considered as novel risk factors in the pathogenesis of T1DM in the Egyptian population.

\section{RECOMMENDATIONS}

Further studies performed on larger sample sizes and another independent Egyptian sample, are recommended to validate and confirm our findings among Egyptian population. Moreover, additional studies are needed to clarify the functional effect of the rs2910164 and rs11614913 polymorphism in immune cells as well as pancreatic $\beta$-cells.

Financial support and sponsorship: Nil.

\section{Conflict of interest: Nil.}

\section{REFERENCES}

1. Mobasseri M, Shirmohammadi M, Amiri T et al. (2020): Prevalence and incidence of type 1 diabetes in the world: a systematic review and metaanalysis. Health Promot Perspect, 10(2):98-115.

2. Cammaerts S, Strazisar M, De Rijk P et al. (2015): Genetic variants in microRNA genes: impact on microRNA expression, function, and disease. Front Genet., 6:186-191.

3. Jameel Z, Lawi Z, Al-Dujaili N (2019): Investigation of Micro-RNA gene polymorphism (rs11614913) in patients with type 2 diabetes in Najaf City. Biochem Cell Arch., 19(1): 2027-2030.

4. Hoffman A, Zheng T, Yi C et al. (2009): microRNA miR-196a-2 and breast cancer: a genetic and epigenetic association study and functional analysis. Cancer Res., 69:5970-7.

5. Ibrahim A, Ramadan A, Wahby A et al. (2019): Micro-RNA 196a2 expression and miR-196a2 (rs11614913) polymorphism in T1DM: a pilot study. J Pediatr Endocrinol Metab., 32(10):1171-1179.

6. Xu J, Chen Q, Zen K et al. (2013): Synaptosomes secrete and uptake functionally active microRNAs via exocytosis and endocytosis pathways. J Neurochem., 124:15-25.

7. Assmann T, Duarte G, Brondani L et al. (2017): Polymorphisms in genes encoding miR-155 and miR$146 \mathrm{a}$ are associated with protection to type 1 diabetes mellitus. Acta Diabetol., 54:433-41.

8. Roderburg C, Luedde T (2014): Circulating microRNAs as markers of liver inflammation, fibrosis and cancer. J Hepatol., 61:1434-1437.

9. Hassan F, Khatab A, Abo El-Fotoh W et al. (2019): Prevalence of diabetes mellitus among school-age children. Menoufia Med J., 32:305-10.

10. Khan M, Rahman B, Haq $T$ et al. (2021): Deciphering the Variants located in the miR196a2, miR146a, and miR423 with type-2 diabetes mellitus in Pakistani Population. Genes, 12: 664-68.

11. Esguerra $J$, Nagao $M$, Ofori $J$ et al. (2018): MicroRNAs in islet hormone secretion. Diabetes Obes. Metab., 20:11-19. 